\title{
Factors Differentiating Research Involvement among Faculty Members: A Perspective from Cambodia
}

\author{
Phyrom Eam, a,* \\ ${ }^{a}$ Hiroshima University, Japan
}

\begin{abstract}
Despite very low research involvement and productivity of its faculty, research activities are not totally absent at Cambodian higher education institutions. This study seeks to diagnose influential factors that differentiate between Cambodian faculty who get involved in research activities and those who do not, with special emphases placed on involvement in research activities that are decently context-specific. Self-reported survey questionnaires were administered to faculty at ten selected Cambodian universities; the total sample (with usable returned questionnaire sets) amounted to 444 faculty members. Drawing on logistic regression analysis, the study detected that faculty obtaining their terminal degrees abroad, being full-timers, spending more time on research, and having high research self-efficacy were more likely to engage in research activities. As for institutional characteristics, large faculty size and available research funding sources were also correlated with research involvement. This study situates the findings in the research context of Cambodian higher education and discusses the practical meanings that the statistically significant variables imply.
\end{abstract}

\begin{abstract}
Abstrak
Walaupun tingkat partisipasi dan produktivitas penelitian dosen sangat rendah, kegiatan penelitian di beberapa institutsi pendidikan tinggi di Kambodia tidak sepenuhnya hilang. Studi ini berupaya mendiagnosa faktor-faktor pembeda antara dosen yang terlibat penelitian dan yang tidak, dengan penekanan khusus pada penelitian yang layaknya sesuai konteks mereka. Perangkat kuesioner disebarkan dan diisi sendiri oleh para dosen di sepuluh universitas di Kambodia; total sampel (berdasarkan kuesioner yang kembali dan layak analisis) mencapai 444 dosen. Dengan menggunakan analisis regresi logistik, studi ini mendeteksi bahwa dosen yang terlibat penelitian adalah mereka yang mendapatkan gelar dari luar negeri, sudah menjadi dosen tetap, menghabiskan banyak waktu melakukan penelitian, dan mempunyai kapasitas riset yang cukup tinggi. Kaitannya dengan karakteristik institusi, faktor banyaknya jumlah tenaga dosen dan ketersediaan sumber dana juga berkorelasi dengan tingkat partisipasi penelitian. Studi ini mensituasikan temuan di atas pada konteks pendidikan tinggi Kambodia dan membahas beberapa pemahaman praktis yang terimplikasi dari variabel yang signifikan secara statistik.
\end{abstract}

Keywords: Higher Education Development, Cambodian Research Productivity, Academic Profession, Research Performance, Research Culture

\section{Introduction}

The paradox of "publish or perish" has so far been of great interest among academicians and researchers in the area of higher education development and the academic profession. Pressing needs

*Corresponding author. Address: Graduate School for International Development and Cooperation (IDEC), Hiroshima University, Japan. Email: eamphyrom@yahoo.com. for faculty to publish still remain very high in academia today. Yet, this discourse has just started in slowly-developing contexts of higher education in general and of Cambodia in particular, simply because the majority of faculty members there do not publish and teaching has always been considered as their prime academic role (Chen et al. 2007). Conducting academic research, for most Cambodian universities, has been more like a slogan or a beautiful saying to broach rather than a reality. 


\section{Context of the Study}

The origin of higher education in Cambodia can be traced far back to its glorious past in the Khmer Empire when two elite universities were reportedly established (Sam et al. 2012). Generally, however, studies on Cambodian higher education could only examine the situation after the collapse of the genocidal Khmer Rouge regime - the period wherein the whole formal education system was completely abolished - in 1979, when Cambodian higher education was kick-started and reorganized structurally. Public universities were reopened subsequently and more private ones were established in later years. According to Un and Sok (2014), the revived higher education system was supported by the Soviet Union and the Eastern bloc, a coordination that perhaps partly makes the Cambodian university system oriented more towards teaching and learning than research. Currently, the number of higher education institutions (HEIs) has increased to 105 in total (by 2014), constituting 10,842 teaching staff (in 2014) and approximately 255,791 students enrolled (2012-2013 statistic) (Un and Sok 2014). Like HEIs in other developing countries, Cambodian HEIs have been facing many challenges, from seriously criticized teaching and learning quality to their complicated governance and, currently, to the lack of a research culture and capacity.

\section{Problem Statement}

Burgeoning concerns over academic research issues in this country do not necessarily imply that research development efforts and research activities do not exist at all at Cambodian higher education institutions. 2010 marked the turning point of the government's emphasis on research. The Ministry of Education, Youth and Sport (MoEYS) first issued research policy in July 2010 and then (a year later) the 2011-2015 master plan for strategic research development in Cambodian higher education, along with the establishment of two institutionalized, research-focused bodies: a Scientific Research Department and a Pedagogical Research Department (Chet 2009). More realistically, in a scoping study on Cambodian research capacity, Kwok and colleagues (2010) reported around seven or eight Cambodian public universities engaging in certain research projects. Faculty in those universities might have a chance to engage as consultants or collaborators in research projects funded or co-funded by different types of donors, such as aid agencies, international non-governmental organizations or foreign universities, the study claimed. A few other studies described in a less rigorous way factors affecting low research implementation (Chen et al. 2007; Sam et al. 2012). Those investigations seemed to conclude that there are many explanatory factors leading to the poor research involvement in Cambodia, but the two most concerning macro-level issues have possibly been the structural and cultural factors.

In spite of those few studies, particular investigations based on a clear empirical framework have yet to be conducted on research involvement in the Cambodian context. Most theoretically- and empirically-based research studies in the field of research performance (or involvement in research activities) at HEIs have been accomplished in the Western context (Jung 2012). Little attention has been given to those developing systems of higher education of the emerging economies or the peripheral countries. Worse is that most of those western-context-based studies have focused on research productivity or performance as measured by published articles, books or citation counts, which does not aptly apply to the situation of research in developing higher education contexts whose faculty might be involved in research, but (most) do not publish in wellknown international journals or never publish at all.

\section{Research Objective}

For Cambodia, in short, a genuine lack of adequate empirical research studies on academic research involvement has clearly been a big contextual knowledge gap for most HEIs in this country, especially as the whole higher education system is considering putting greater emphasis on academic research and while the world has been moving forward with scientific research activities. Considering all these concerns, this study worked to bridge the void by investigating relevant individual and institutional variables, both literature- and context-based, to identify influential variables that explain why some Cambodian university lecturers engage (and others do not) in research activities at their institutions.

\section{Conceptual Framework}

\section{Factors Affecting Research Involvement}

In previous research studies, several important attributes (such as personal, psychological, institutional, and/or environmental) were examined to identify their associations with research performance or productivity (Creswell 1985; Jordan et al. 1988; Harris and Kaine 1994; Dundar and Lewis 1998; Teodorescu 2000; Brocato and Mavis 2005; Chen et al. 2006; Edgar and Geare 2014). Consequently, several theoretical and empirical models of factors or correlates of research performance, diverse in terms of disciplines and/or dimensions, emerged. One very common model was found in studies that framed their predictor variables in two levels: individual/personal and institutional levels (Shin and Cummings 2010; Quimbo and Sulabo 2014). Adapting the empirical framework of Shin and Cummings (2010), the researcher modeled this 
study based on a two-major-factor model: individual and institutional factors.

In the literature, the individual factor contained sub-factors, including: demographic or ascriptive (age, sex, etc.), professional or achievement (degree, discipline, time, academic rank, research experiences, etc.), psychological-cognitive (research self-efficacy, research motivation, etc.) and perceptual attributes (perceived role preference, perceived research value, etc.). Age (Blackburn et al. 1978), academic rank (Blackburn et al., 1978; Creswell, 1985), academic discipline (Jung 2012), research motivation (Tien 2000), and research self-efficacy (Pasupathy and Siwatu 2014) were detected as statistically significant correlates of research performance, with different magnitudes of effect size owing to the contexts of study.

No individual characteristic alone was predictive of research performance; institutional or departmental factors were also indispensable drivers that eased or blocked research involvement and productivity. Dundar and Lewis (1998) and Jordan and colleagues (1988), for instance, found that private institutions were more research productive than their public counterparts. McGill and Settle (2012) investigated research performance of computing faculty members and maintained that staff supports, offered time, and available funding were definitely vital for the university to increase the number of prolific researchers. Other significant institutional variables included a high number of paper-publishing members, institutional prestige, research-friendly working conditions, and researchoriented leadership, et cetera.

\section{Measuring Research Involvement}

Creswell (1985), one of the earliest researchers in this field, assumed that three suggested metrics have been and should be the most appropriate tools to measure research performance: research publications, citation counts and peer-rating. Later researchers employed additional and/or different tools according to the context of their studies, such as academic conference proceedings, obtained grants, Integrated Research Productivity Index, et cetera (Chen et al. 2006; Duffy et al. 2011). No fixed, unified system or metric to measure research performance has been agreed upon until now; efforts have thus far been made by various researchers (Bland et al. 2005; Bazeley 2010) to develop one for their particular contexts.

Although it has not been uncommon to use the number of publications or citation counts to measure research performance in the literature, Teichler, Arimoto, and Cummings (2013) posited that addressing only research publications (outputs) as the sole instrument to measure research productivity would leave other important research activities in a "black box." This idea implied that research performance measurement should depend on the nature of the research, not a standardized measure. Also, this argument applies well to the developing context, especially Cambodian higher education. Chen and colleagues (2007) claimed that 90 percent of Cambodian university lecturers do not publish. Thus, to measure research productivity using such indicators as published academic journals or books or citation counts in this context is going to give the researcher with not only inadequate but also improper data for analysis.

This study did not use the number of research publications as the main metric to measure research performance. The researcher referred to the outcome variable of this study as "research involvement" rather than research productivity or research performance. To measure involvement in research activities in the Cambodian HEI context, this study chose to select research activities that fit into and reflected the reality of Cambodia's fragile research conditions. Two major studies offered the ground for developing a "research involvement" tool in this study. First, the study of Wylie-Rosett and colleagues (1990) used a four-level research continuum (implementation of research initiatives, conducting research, translation of research into practice and application of research to practice) to conceptualize involvement in research activities (as cited in ByhamGray et al. 2006).

A similar, more practical tool used to measure research activities is the "Research Spider" framework (Smith et al. 2002) — a tool that comprises ten commonly engaged researcher activities. Based on the two theoretical and practical works, therefore, the study produced a nine-item scale aimed at measuring the level of engagement: (1) applying for research funding; (2) managing research projects; (3) designing research frameworks, methods and procedures; (4) critically reviewing the literature; (5) publishing research articles; (6) presenting research results at academic conferences; (7) analyzing, writing and presenting research reports for donors or stakeholders; (8) disseminating research findings to the public; and (9) using research results to teach in classrooms. These items were measured with a five-option Likert scale (with $1=$ "not engaged at all" to 5 = "engaged very actively"). The items and the whole questionnaire were checked by the researcher's academic supervisor, five senior researchers in the field of education, and three conveniently-selected Cambodian university lecturers, and then pilottested with 30 faculty members from two different Cambodian universities. Some refinement was made with the scale items and the language used in order to ease understanding of the questionnaire contents.

The results of the preliminary analysis revealed that the research involvement of the 444 respondents was very low (Mean $=1.82$; Median $=1 ;$ S.D. $=1.2 ;$ Skewness $=1.15$; and Kurtosis $=-.17$ ), and 
Figure 1. Conceptual Framework of Faculty Involvement in Research Activities

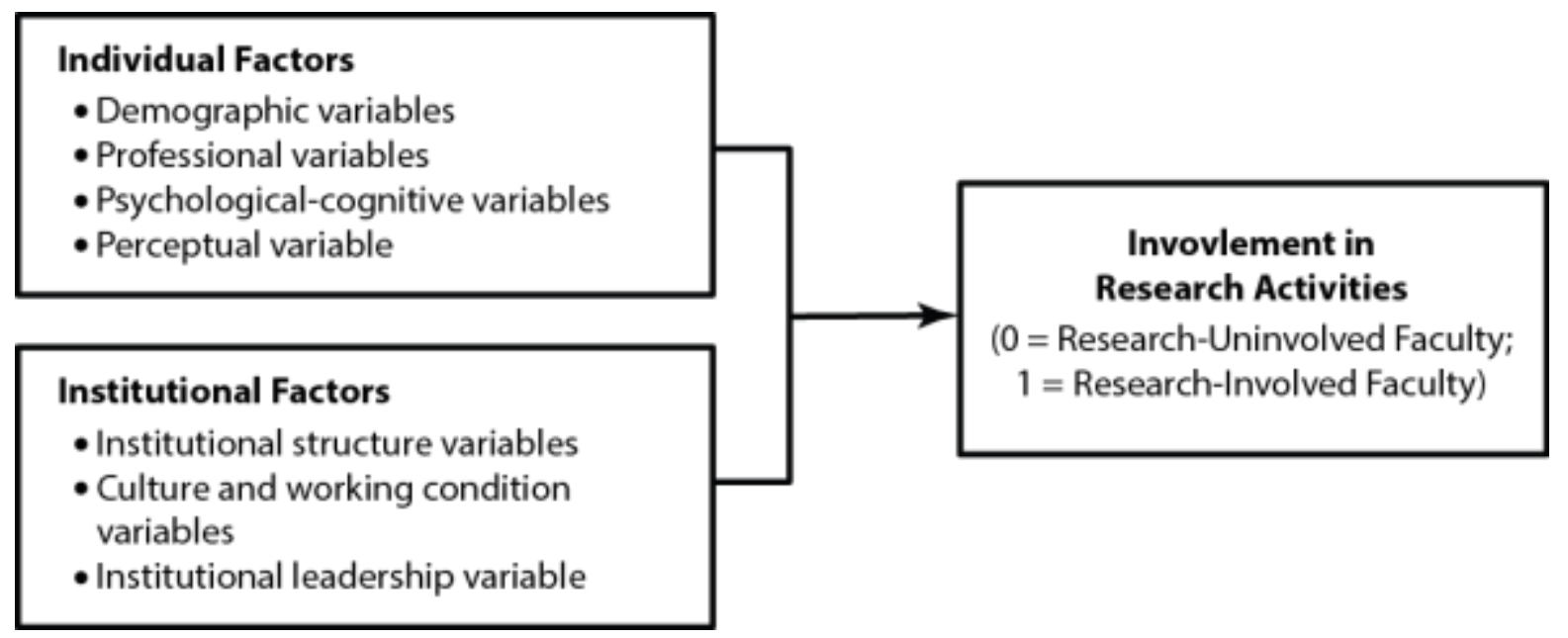

Source: Created by the Author.

the distribution of the research involvement variable was obviously not normally distributed since most respondents did not engage at all in the nine research activities, as proven by the skewness value higher than 1. Thus, the researcher decided to use the median score as a benchmark to convert the interval-scale research involvement into a dichotomous variable of two levels: $0=$ research-uninvolved faculty (those with a median score equal to 1 or lower) and $1=$ research-involved faculty (those with scores greater than 1). Finally, this process produced two groups of respondents: 35.1 percent research-involved faculty and 64.9 percent those who never involved in research at all.

\section{Research Methods}

\section{Participants and Data Collection}

Participants in this investigation were the so-called "university lecturers" working in 10 selected Cambodian HEIs, of which seven are public institutions and three are private. The selected participants were from a range of majors, but classified into two main academic fields in the analysis: 1) Social sciences, humanities, and business-related fields and 2) Sciences, engineering, and related fields.

A seven-page questionnaire set was developed, containing 47 key items or questions and organized into three main sections, each comprising a number of variables: (1) Section A was about personal information and their institutional and working conditions, (2) Section $\mathrm{B}$ focused on their research attitudes and perceptions of research, and (3) Section C centered on the detailed characteristics of past academic research engagement. The questionnaire was checked and pilot-tested to ensure its construct and content validity, as mentioned earlier. For actual data collection, the questionnaire was distributed in hard copies to the target respondents, who worked with it within a period of three weeks (on average) and returned the completed copy to the researcher by the end date. The total period of data collection from the 10 universities lasted for almost two months (from May 6, 2013 to June 20, 2013). It should be noted that the researcher intended to obtain a very large sample size, so due to the fact that a huge loss of subjects was expected, the questionnaire was distributed to all approachable lecturers at each university. Unfortunately, not all lecturers returned the questionnaire, which yielded only a moderate return rate of 44.7 percent, an exact equivalent of 465 returned questionnaires out of the 1040 sets actually distributed. Of the 465 questionnaires, only 444 were usable. Excluded returned questionnaires were simply those obtaining a high percentage of inadequate answers (less than 50 percent of the answers), those with missing values on key variables, or those answered by untargeted respondents such as in-contract practicum lecturers.

\section{Variables and Measures}

The outcome variable categorized Cambodian lecturers into two groups: those involved in research activities and those uninvolved. The data suggested that 64.9 percent of respondents were not involved at all in any research activities over the past five years and the remaining 35.1 percent were only involved in certain ways. As for predictor variables, after the data collection and the Exploratory Data Analysis (EDA), twenty of them-14 individual factor variables and six institutional ones-were inputted into the logistic regression analysis, with their measurement and description presented in Table 1. 
Table 1. Detailed Description and Statistics of Study Variables

\begin{tabular}{|c|c|c|c|c|c|}
\hline Variables & Description/coding & $\mathbf{f}$ & $\%$ & Mean & SD \\
\hline Research involvement & $0=$ Research-uninvolved faculty & 288 & 64.9 & & \\
\hline$(\mathrm{n}=444)$ & $1=$ Research-involved faculty & 156 & 35.1 & & \\
\hline
\end{tabular}

\section{Individual factors}

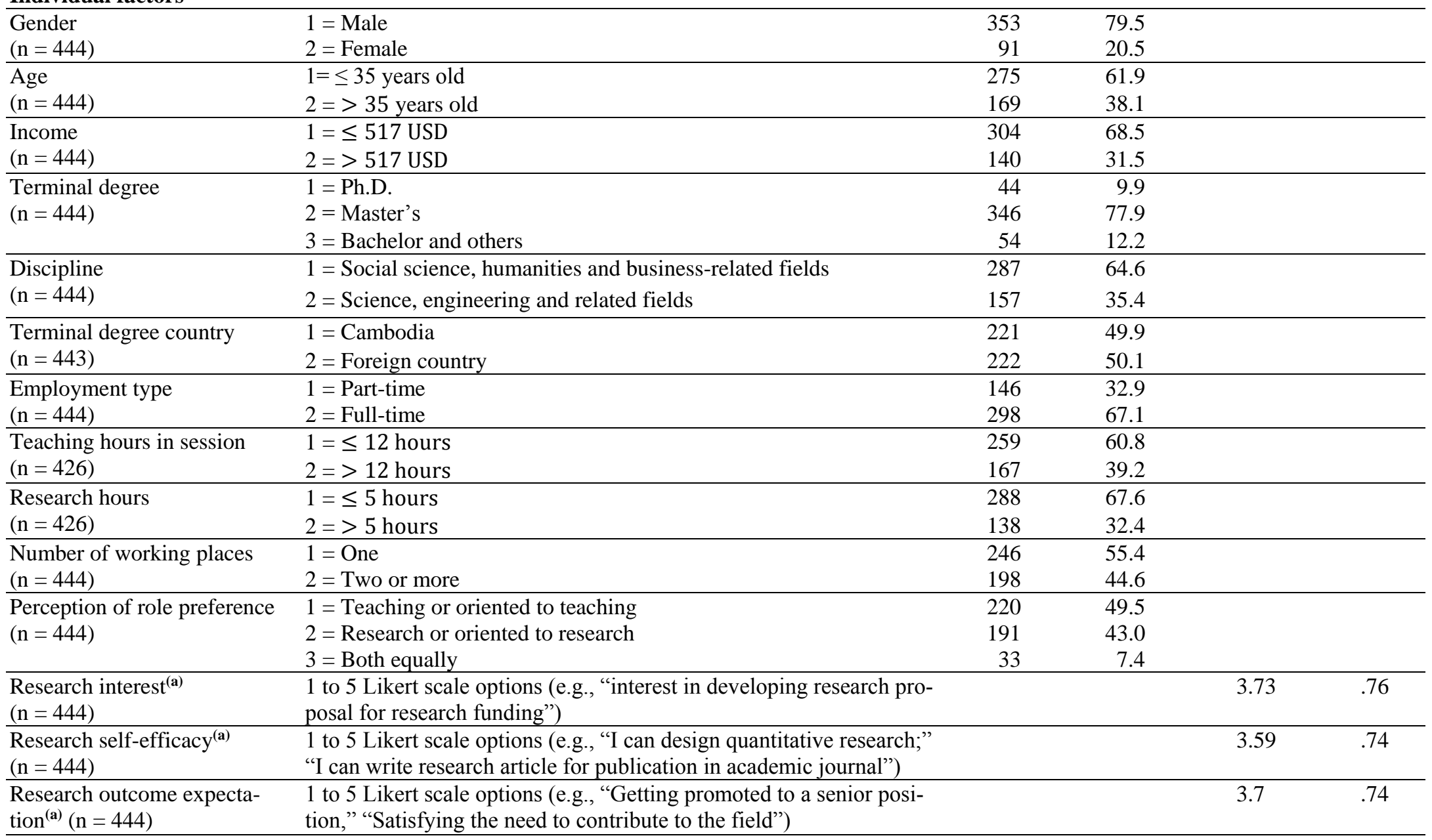

\section{$\underline{\text { Institutional factors }}$}

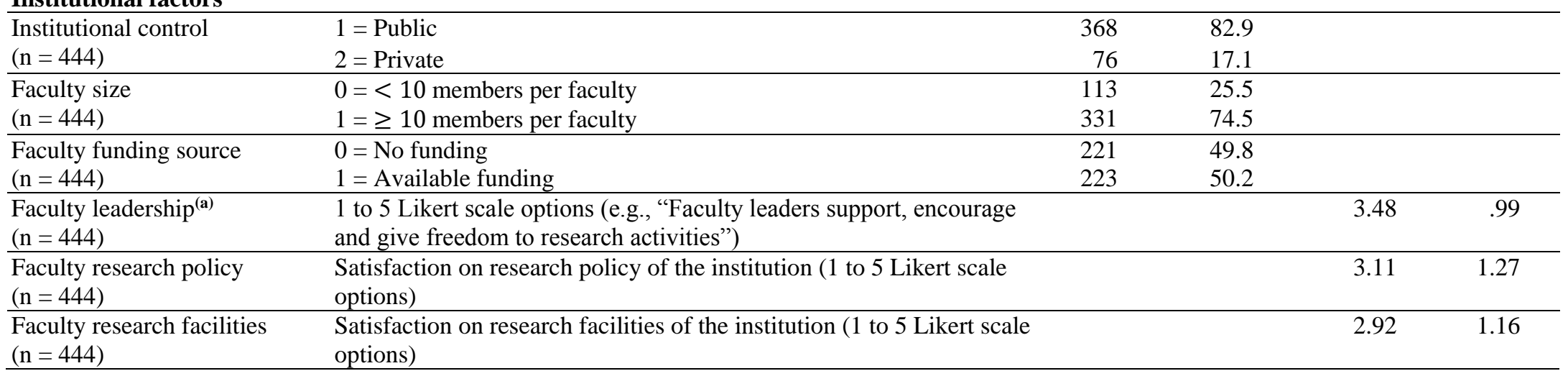

Note: ${ }^{\text {(a) }}$ Research self-efficacy (12 items; Cronbach's $\propto=.94$; adapted from Kahn and Scott 1997); research interest (11 items; Cronbach's $\propto=.93$; adapted from Bishop and Bieschke 1994, as cited in Vaccaro 2009: 148); research outcome expectation (8 items; Cronbach's $\propto=.81$; adapted from Chen et al. 2006); and faculty leadership ( 3 items; Cronbach's $\propto=.82$, adapted from Changing Academic Professions (CAP) Survey, version 2006, in Teichler et al. 2013). All of these attitudinal variables were adapted and adjusted to fit the study context. 


\section{Statistical Analysis}

Collected data were analyzed in SPSS software application (version 21). To realize the research objective, the study employed logistic regression analysis, and used a blocked, backwards step-wise method to analyze the data, deriving two models - Model 1: Individual factors and Model 2: Institutional factors. The use of the stepwise method was due to the fact that the study was the very first exploratory quantitative study on this research domain in the context of Cambodian HEIs. The use of a block entry indicated that the researcher was interested in exploring the main effects of each major factor (by controlling for the other factor) in predicting the probability that each group of the outcome variable could occur.

Speaking of statistical assumptions for the analysis, two key points were considered: case influence and multi-colinearity. First, in order to avoid any case influence in the analysis, Cook's distance statistic was used to test whether there were any influential cases that manipulated the accuracy of the results. Results suggested that there was no detected case influencing the analysis, as expressed by the value of Cook's distance of each case lower than 1 ( Min = .00002 , Max $=.213$, Mean $=.022, \mathrm{SD}=.033$ ). Second, the researcher used a multiple regression analysis method to observe the Tolerance and Variance Inflation Factor (VIF) value of the scale variables to see if there was any possibility that the problem of multi-colinearity (namely, the high correlation among independent variables inputted) existed in the model. Tolerance (Min $=.39$, Max $=.92$, Mean $=.71, \mathrm{SD}=.15)$ and VIF $(\operatorname{Min}=1.1, \operatorname{Max}=2.59$, Mean $=1.5 ; \mathrm{SD}=3.9)$ confirmed no problem of multi-colinearity affecting the results of the analysis.

\section{Findings}

This study worked to identify significant predictors of individual and institutional factors that differentiate between faculty who are involved and those who are not involved in research activities.

\section{Model-Fit Statistic}

The result of the analysis, as appearing in Table 2, suggested that the constant model (null model) was statistically significant (Waldstatistics $=32.71, \mathrm{p}<.001$ ), with the correct predicting ability of 64.1 percent, given no inclusion of any predictors. Block one model-fit statistics was also significant $(\mathrm{p}<.001)$ with the value of Chi-square $\left(X^{2}=117.64\right)$, suggesting that the whole individual model obtained variables that had significant effects on the variation of the dichotomous outcome variable, with an increased level of predicting ability to 74.3 percent. The model-fit statistic of model 2 , as shown in the same table $\left(X^{2}=149.89, \mathrm{p}<.001\right)$, showed that the institutional-level factor also had significant predicting ability on research involvement of Cambodian faculty. Further analysis on model-fit statistic, using Hosmer and Lemeshow inferential goodness-of-fit test, also significantly proved the model fit, with model 1 having the value of $\left(X^{2}=4.416 ; \mathrm{df}=8 ; \mathrm{p}=.818\right)$, and model 2 $\left(X^{2}=11.54 ; \mathrm{df}=8 ; \mathrm{p}=.173\right)$. Both of the insignificant $\mathrm{p}$-values suggested that the inclusion of these individual and institutional variables does not affect the accuracy of the analysis.

Table 2. Model-Fit Statistic

\begin{tabular}{lccc}
\hline Block (Model) & $\begin{array}{c}\% \\
\text { Correct }\end{array}$ & $\begin{array}{c}\text { Model coefficient } \\
(\text { Sig) }\end{array}$ & $\begin{array}{c}\text { Statistical } \\
\text { test }\end{array}$ \\
\hline Block 0 (Constant) & 64.1 & $32.71^{*}$ & Wald statistic \\
Block 1 (Model 1) & 74.3 & $117.64^{*}$ & Chi-square \\
Block 2 (Model 2) & 77.4 & $149.89^{*}$ & Chi-square \\
\hline Note: $*$ p $<.001$. & & &
\end{tabular}

\section{Model 1: Individual Factors}

Table 3 demonstrates the statistical proof to answer the hypothesis testing whether the individual factors posed any effects on the outcome variable. The regression of the dichotomous (involved-ornot-involved) outcome variable on the 14 predictor variables of model 1 appeared to conclude four key variables to be the significant predictors of research involvement of Cambodian faculty. The four significant predictors at the individual level were: obtaining terminal degree from a foreign country $(B=1.3, \operatorname{Exp}(B)=3.67, p$ $<.001)$; being a full-time lecturer $(\mathrm{B}=1.67, \operatorname{Exp}(\mathrm{B})=5.3, \mathrm{p}<$ $.001)$; obtaining high allocated research hours $(\mathrm{B}=.87, \operatorname{Exp}(\mathrm{B})=$ $2.38, \mathrm{p}<.001)$; and possessing a strong self-efficacy on research $(\mathrm{B}$ $=.62, \operatorname{Exp}(\mathrm{B})=1.85, \mathrm{p}<.05)$.

The model showed no statistically significant relationship between other observed individual variables (gender, age, income, discipline, teaching hours in session, and number of working places) and research involvement. Likewise, research interest, research outcome expectations, and role preference did not explain whether Cambodian faculties engaged or did not engage in research activities, statistically speaking.

It should be noted that the interpretation of effect size for each individual significant predictor was based on the Exp (B) values, a proxy of the odds ratio. According to Table 3 below, Cambodian lecturers who obtained their degree overseas were about three to four times $(\operatorname{Exp}(B)=3.67)$ more likely to engage in research activities than their locally graduating counterparts. The odds ratio of one unit change in the other two significant predictor variables (that is, high research hours with $\operatorname{Exp}(B)=.87$ and research self-efficacy 
Table 3. Logistic Regression Results of Model 1 and Model 2

\begin{tabular}{|c|c|c|c|c|c|c|c|c|c|}
\hline \multirow[b]{2}{*}{ Variables } & \multicolumn{3}{|c|}{ Constant Model } & \multicolumn{3}{|c|}{ Model 1} & \multicolumn{3}{|c|}{ Model 2} \\
\hline & $\mathbf{B}$ & S.E & $\operatorname{Exp}(B)$ & $\mathbf{B}$ & S.E & $\operatorname{Exp}(B)$ & $\mathbf{B}$ & S.E & $\operatorname{Exp}(B)$ \\
\hline Intercept & $-.58 * *$ & .102 & .559 & $-4.73 * *$ & 1.12 & .009 & $-6.05 * *$ & .92 & .002 \\
\hline \multicolumn{10}{|l|}{ Individual factors } \\
\hline $\begin{array}{l}\text { Terminal degree country } \\
(1=\text { Cambodia, } 2=\text { Foreign })\end{array}$ & & & & $1.3 * *$ & .27 & 3.67 & $1.21 * *$ & .28 & 3.36 \\
\hline $\begin{array}{l}\text { Employment type } \\
(1=\text { Part-time, } 2=\text { Full-time })\end{array}$ & & & & $1.67 * *$ & .34 & 5.3 & $1.23 * *$ & .34 & 3.42 \\
\hline $\begin{array}{l}\text { Research hours } \\
(1=\leq 5 \text { hours }, 2=>5 \text { hours })\end{array}$ & & & & $.87^{*}$ & .26 & 2.38 & $.84 *$ & .27 & 2.31 \\
\hline Research self-efficacy & & & & $.62 *$ & .22 & 1.85 & $.6^{*}$ & .18 & 1.82 \\
\hline \multicolumn{10}{|l|}{ Institutional factors } \\
\hline $\begin{array}{l}\text { Faculty size } \\
(0=<10,1=\geq 10)\end{array}$ & & & & & & & $.89 *$ & .39 & 2.44 \\
\hline $\begin{array}{l}\text { Faculty funding source } \\
(0=\text { No funding, } 1=\text { Available })\end{array}$ & & & & & & & $1.28 * *$ & .26 & 3.58 \\
\hline Cox and Snell $\mathbf{R}^{2}$ & & & & & .24 & & & .30 & \\
\hline Nagelkerke $\mathbf{R}^{2}$ & & & & & .33 & & & .41 & \\
\hline
\end{tabular}

Notes: $*(\mathrm{p}<0.05), * *(\mathrm{p}<0.001)$; the first level was set to be the reference group.

with $\operatorname{Exp}(\mathrm{B})=1.85)$ also confirmed a moderate effect on whether or not Cambodian university lecturers engaged in research activities. Also statistically significant was being full-time faculty, with the Exp (B) value of 5.3, indicating an equivalent effect size of around five times more research-engaged than the part-timers. The value of Cox and Snell $\mathrm{R}^{2}$ of .24 (and Nagelkerke $\mathrm{R}^{2}$ of .30), in this study, indicated a low to moderate ability of the four significant predictors of the individual level in predicting the Cambodian lecturers' research involvement - namely, the model explained 24 percent of variances in determining whether Cambodian lecturers were involved or not involved in research activities at their institutions over the past five years.

\section{Model 2: Institutional Factors}

Model 2 of the analysis added the six institutional-level variables into the analysis, controlling for the individual factor variables. The results suggested that two institutional predictors, funding availability and faculty size, were statistically significant in associating with whether or not Cambodian university lecturers engaged in research activities. Whether the university was public or private did not pose effects on the involvement of research activities. Researchoriented leadership, satisfaction with research facilities, and satisfaction with research policies of the institution were also not detected to be significant predictors in this study.
The effect-size interpretation was the same for model 2 as it was in model 1. Large faculty size $(B=.89, \operatorname{Exp}(B)=2.44, p<.05)$ suggested that academics employed in a larger department (one with more than 10 faculty members) were approximately two to three times more likely to engage in research activities than those from a smaller department. Likewise, lecturers from departments or institutions with available funding sources were up to three to four times more likely to engage in research activities than those who came from research-funding-unavailable institutions $(\mathrm{B}=1.28$, Exp $(B)=3.58, p<.001)$. However, these two significant variableslarge faculty size and available funding sources - together explained just a trivial 6 or 8 percent of the variation in the outcome variable, with the changed value of Cox and Snell $\mathrm{R}^{2}$ from .24 to .30 , and the changed value of Nagelkerke $\mathrm{R}^{2}$ from .33 to .41. All elaborated statistically significant results appear in Table 3.

\section{Discussion}

In the attempt to test the association between individual and institutional factors and research involvement, this study detected six statistically significant variables, all together reflecting that research-engaged faculty in Cambodia are influenced by their research competence, time devoted to research, and their faculty size and financial supports. 


\section{Individual Research Competence and Time Availability}

The contextual literature of research at Cambodian HEIs had no reluctance to call for a steadfast emphasis on individual research competence and increased academic professionalization of Cambodian faculty (Kwok et al. 2010; Sam et al. 2012). Along the same lines, other studies in different contexts also acknowledged the significant relationship between research self-efficacy and research involvement or productivity (Pasupathy and Siwatu 2014). Brocato and Mavis (2005) focused on the psychological and cognitive factors, revealing in his study that research skills and deep knowledge in subject areas had positive significant influences on individual research productivity. Based on statistical evidence from 444 Cambodian faculty responses, this study offers additional evidence that the individual factor is indeed associated with research involvement. In this study, research self-efficacy was a key variable detected to have significant correlation with research involvement, with the statistically significant effect size of $\operatorname{Exp}(B)=1.85$.

The place where respondents obtained their highest degree was also found to be a stout determinant of whether or not Cambodian lecturers were involved in research activities, with the overseas graduates having the effect size of three to four times (Exp B = 3.67) more engaging than their locally graduating counterparts. In fact, the terminal degree obtaining country can be a proxy for the quality of graduate training programs found significantly related with research performance in most studies in the literature (see Ramsden 1994), and that further reflects the research competence of those graduates. For Cambodia, the large gaps between the quality of graduate programs of the local HEIs and those in more developed foreign countries are certainly obvious, especially in terms of research training and institutional research capacity. While Cambodian local graduates are only passively exposed to the world of academic research during their graduate study due to the lack of access to academic resources and financial supports, Cambodian graduates overseas (say, from Japan, the United States or Australia) may better experience a scholarly atmosphere as they can frequently attend academic conferences and/or publish their research papers, and hence have not only a stronger ability to conduct academic research in their fields, but also a bigger academic network sphere, all undoubtedly contributing to their future research engagement.

Allocating more hours to research activities has been proven to be highly correlated with high research performance or productivity. This finding was detected as significant, for example, in the study of Brocato and Mavis (2005), Chen and colleagues (2006), and Jung (2012), all arguing that time spent on research tremendously affects research productivity of individual academics. A conventional notion in Cambodia is that most academics spend their time on teaching, and, even worse, some do work in more than two universities and possibly in other areas rather than the academia. Kwok and his co-researchers (2010) noted that Cambodian university lecturers perceived themselves as teachers (rather than researchers) and so spent lots of hours teaching to earn extra income and thus had less time to focus on research. It was detected that fewer teaching hours would allow academics to possess more available time to concentrate on research activities more conveniently (Chen et al. 2007).

In like manner, whether a Cambodian faculty was a full-timer or a part-timer could also affect the possibility for him or her to be involved in research activities (odds ratio $=5.3$ for the full-time lecturers). Previous researchers claimed that full-time academics were more likely to produce research outputs as they had a good motivation to engage in research activities and because they spent less time teaching and had more professional contact and both vertical and horizontal collaboration (Blackburn et al. 1978). In the Cambodian context, full-time lecturers are mostly those with tenure, literally meaning that they have to spend more time working in their offices and so obtain more opportunities to discuss and collaborate in research projects with their officemates, especially those offices with one or more active researchers. Data from the descriptive analysis in this study suggested that 84 percent of research-engaged Cambodian lecturers worked in collaboration on their research projects, mostly with their colleagues. Part-timers, on the other hand, hop from one workplace to another and so have less (perhaps no) time for research. Simply put, the finding implies that time availability, like research competence, is crucial for research involvement.

\section{Faculty Size and Financial Sources}

With some logical explanations of research involvement in the Cambodian context, results of the current study suggest that individual academics from Cambodian universities with large faculty sizes were more oriented towards research engagement. A number of past studies of institutional effects on research productivity were consistent with this finding (see, for example, Blackburn et al. 1978; Dundar and Lewis 1998). In the reality of Cambodian HEIs, having a large faculty size suggests a more promising internal partnership and a more likely collaboration to seek grants and to work together on various funded research projects. Large faculty size often means that faculty can share more knowledge and skills about the specialized fields. Namely, large faculty size can offer more time for "mentorship" among colleagues, which Jordan and colleagues (1988) called the "synergistic effect of large size." In Cambodian university departments, it is possible that large faculty size might contain one or more active, prolific researchers who are capable of obtaining research grants and so push up the research capacity of the team at large. As an implication, a strong, trustworthy research network 
and collaboration are likely to emerge in the large faculty of Cambodian universities.

Almost no literature on research performance/productivity has rejected the fact that funding is one of the most important visible inputs to accelerate the development of a research culture and increase research productivity at HEIs. Johnston (1994), among the first researchers in the field of research productivity, concluded in his study focusing on resource concentration on research productivity that "Large, well-funded, and well-led research groups produce more publications, of higher impact...." That condition of financial sources and additional support also determines the engagement in research of Cambodian faculties. The result of this study suggests that no funding perhaps means no little or research is taking place. Kwok and other researchers (2010) reaffirmed the importance of funding sources (referring to the funding mainly obtained from the external donors in their study) in making research activities possible at certain Cambodian universities. External financial research supports may contribute significantly to the increase in research productivity (Dundar and Lewis 1998). No doubt, funding has been one of the most conventionally concerning aspects in the attempt of the Cambodian system to bring about more research involvement.

While the individual factor variables explained 24 percent of the variation, the institutional variables represented only 6 percent of the variation in research engagement. Previous studies (Harris and Kaine 1994) found a similar trend. For Cambodia, it should be noted that despite relatively different to a certain degree in terms of their conditions and overall performance, the local universities are mostly characterized by the lack of enough research resources, funding and other academic conditions that can ensure high research quality. These universities have been functioning only as teaching-learning institutions so far. This situation implies that the low variation of institutional research supports and environments among universities might be an undeniable scenario, further suggesting that, in the current setting, whether Cambodian faculty are research-engaged or not is more likely a function of their individualities than their institutional conditions.

\section{Limitations}

Though one of the research significances was the use of a quantitative approach to study the empirical and contextual predictors of research involvement, the methodological caveat is still worth taking into consideration. First, this study was a single level study, so it did not handle the variances explained by different levels (university level, faculty level, etc.). The study also focused less on the institutional factor variables due to the difficulty and time-constraints in collecting valid and reliable institutional data from the administration of each university. Another limitation is the measurement of involvement in research activities. The study focused on the context-specific aspects of research involvement and so may have deviated from the theoretical (or standardized) ways of measuring research productivity or performance. Thus, further studies should observe how productive Cambodian researchers are in term of scholarly and scientific publications.

\section{Conclusion}

The conceptual model based exclusively on the two empirical factors (i.e., individual and institutional) was indeed proven to be significant in explaining the variance in the research involvement of Cambodian lecturers, with certain significant variables supported by the literature. Despite this, the study's statistical results conclude that individual factors related to the willingness to spend time on research and faculty's research competence are more influential in the decision to engage or not in research activities at their institutions, at least for the current situation. Only such willing Cambodian faculty can actually survive in the academic sphere of their professional lives. Many others decide to go with the conventional flow, striving to spend more hours teaching or working in other institutions to earn extra pay and ignore the academic profession while putting blame on the lack of supports. As is true in the context of many developing countries, the dearth of government and institutional supports are obvious and cannot be denied. Yet, the lack of financial supports should not be the sole factor that hampers future research implementation at Cambodian universities, for, as Creswell (1985) put it, developing a proper atmosphere for research is not beholden to only financial considerations. The implication from this study in the larger social context of Cambodian higher education is quite straightforward: namely, Cambodian faculty should begin to rethink their academic professionalization, taking into consideration their important roles as the think-tanks of the nation, the ones who matter greatly in re-building and developing Cambodia. In a strict sense for them, not being involved in academic and advanced research is perhaps more than just academic perishing.

Even though the (statistically significant) size of the faculty and available funding sources did not add much more to the individual factors in explaining the degree of research involvement of Cambodian university lecturers, the researcher still strongly agrees with the comments of Jung (2012), who stated that institutional factors should remain very crucial elements to consider in practical settings to enhance research capacity of HEIs as they are more amendable and controllable. Like most previous researchers, this researcher envisions that the two factors must be taken into consideration if the Cambodian system is really to look forward to advance the research involvement of its faculty members. 


\section{References}

Bazeley, Pat. 2010. "Conceptualising Research Performance." Studies in Higher Education 35 (8): 889-903.

Blackburn, Robert T., Behymer E. Charles, and Hall D. David. 1978. "Research Note: Correlates of Faculty Publications." Sociology of Education 51 (2): 132-141.

Bland, Carole J., Center A. Bruce, Finstad A. Deborah, and Risbey R. Kelly. 2005. "A Theoretical, Practical, Predictive Model of Faculty and Department Research Productivity." Academic Medicine 80 (3): 225-237.

Brocato, Joseph J., and Mavis Brain. 2005. "The Research Productivity of Faculty in Family Medicine Departments at U.S. Medical Schools: A National Survey." Academic Medicine 80 (3): 244-252.

Byham-Gray, Laura D., Gilbride A. Judith, Dixon L. Beth, and Stage K. Frances. 2006. "Predictors for Research Involvement among Registered Dietitians." Journal of the American Dietetic Association 106 (12): 2008-2015.

Chen, Ching-Yaw, Sok Phyra, and Sok Keomony. 2007. "Benchmarking Potential Factors Leading to Education Quality: A Study of Cambodian Higher Education." Quality Assurance in Education 15 (2): 128-148.

Chen, Yinning, Gupta Ashok, and Hoshower Leon. 2006. "Factors That Motivate Business Faculty to Conduct Research: An Expectancy Theory Analysis." Journal of Education for Business: 179-189.

Chet, Chealy. 2009. "Higher Education in Cambodia." In The Political Economy of Educational Reform and Capacity Development in Southeast Asia: Cases of Cambodia, Laos and Vietnam, edited by Yasushi, Hirosato, and Yuto Kitamura, 153-165. Dordrecht: Springer.

Creswell, John W. 1985. Faculty Research Performance: Lessons from the Sciences and the Social Sciences. Washington, D.C.: Association for the Study of Higher Education.

Duffy, Ryan D., Jadidian Alex, and Webster D. Gregory. 2011. "The Research Productivity of Academic Psychologists: Assessment, Trends, and Best Practice Recommendations." Scientometrics 89: 207-227.

Dundar, Halil, and Lewis R. Darrell. 1998. "Determinants of Research Productivity in Higher Education." Research in Higher Education 39 (6). 607-632.

Edgar, Fiona, and Geare, Alan. 2014. "Factors Influencing University Research Performance." Studies in Higher Education 38 (5): 774-792.

Harris, Geoff, and Kaine Geoff. 1994. "The Determinants of Research Performance: A Study of Australian University Economists." Higher Education 27: 191-204.
Johnston, Ron. 1994. "Effects of Resource Concentration on Research Performance." Higher Education 28 (1): 25-37.

Jordan, John M., Meador, Mark, and Walters, J. K. Stephen. 1988. "Effects of Department Size and Organization on the Research Productivity of Academic Economists." Economics of Education Review 7 (2): 251-255.

Jung, Jisun. 2012. "Faculty Research Productivity in Hong Kong across Academic Discipline." Higher Education Studies 2 (4): $1-13$.

Kahn, Jeffrey H., and Scott A. Norman. 1997. "Predictors of Research Productivity and Science-Related Career Goals among Counseling Psychology Graduate Students." The Counseling Psychologist 25 (1): 38-67.

Kwok, Kian-Woon, Chan, Sopheap, Heng, Chinda, Kim, Sedara, Neth, Baromey, and Thon, Vimealea. 2010. Scoping Study: Research Capacities of Cambodia's Universities. Phnom Penh: Cambodia Development Resource Institute.

McGill, Monica M., and Settle, Amber. 2012. "Identifying Effects of Institutional Resources and Support on Computing Faculty Research Productivity, Tenure, and Promotion.” International Journal of Doctoral Studies 7: 167-198.

Pasupathy, Rubini, and Siwatu, O. Kamau. 2014. “An Investigation of Research Self-Efficacy Beliefs and Research Productivity among Faculty Members at an Emerging Research University in the USA." Higher Education Research \& Development 33 (4): 728-741.

Quimbo, Maria Ana T., and Sulabo C. Evangeline. "Research Productivity and Its Policy Implications in Higher Education Institutions." Studies in Higher Education 39 (10): 1955-1971.

Ramsden, Paul. 1999. "Predicting Institutional Research Performance from Published Indicators: A Test of a Classification of Australian University Types." Higher Education 37 (4): 341358.

Sam, Rany, Zain M. A. Nurulazam, and Jamil Hazri. 2012. "Cambodia's Higher Education Development in Historical Perspectives (1863 - 2012)." International Journal of Learning \& Development 2 (2): 224-241.

Shin, Jung C., and Cummings K. William. 2010. "Multilevel Analysis of Academic Publishing across Disciplines: Research Preference, Collaboration, and Time on Research." Scientometrics 85: 581-594.

Smith, Helen, Wright David, Morgan Stephen, and Dunleavey Joan. 2002. "The 'Research Spider': A Simple Method of Assessing Research Experience." Primary Health Care Research and Development 3: 139-140.

Teichler, Ulrich, Arimoto Akira, and Cummings K. William. 2013. The Changing Academic Profession: Major Findings of a Comparative Survey. Dordrecht: Springer. 
Teodorescu, Danial. 2000. "Correlates of Faculty Publication Productivity: A Cross-National Analysis." Higher Education 39 (2): 201-222.

Tien, Flora F. 2000. "To What Degree Does the Desire for Promotion Motivate Faculty to Perform Research?" Research in Higher Education 41 (6): 723-752.

Un, Leang, and Sok Say. 2014. "Higher Education Governance in Cambodia." In Leadership and Governance in Higher Education, edited by Sjur Bergan, Eva Egron-Polak, Jürgen Kohler, Lewis Purser, and Athanassia Spyropoulou (Vol. 4, pp. 72-94). Berlin, Germany: DUZ Verlags.

Vaccaro, Nicole. 2009. "The Relationship between Research SelfEfficacy, Perceptions of the Research Training Environment and Interest in Research in Counselor Education Doctoral Students: An Ex-Post-Facto, Cross-Sectional Correlational Investigation." PhD diss., University of Central Florida. 